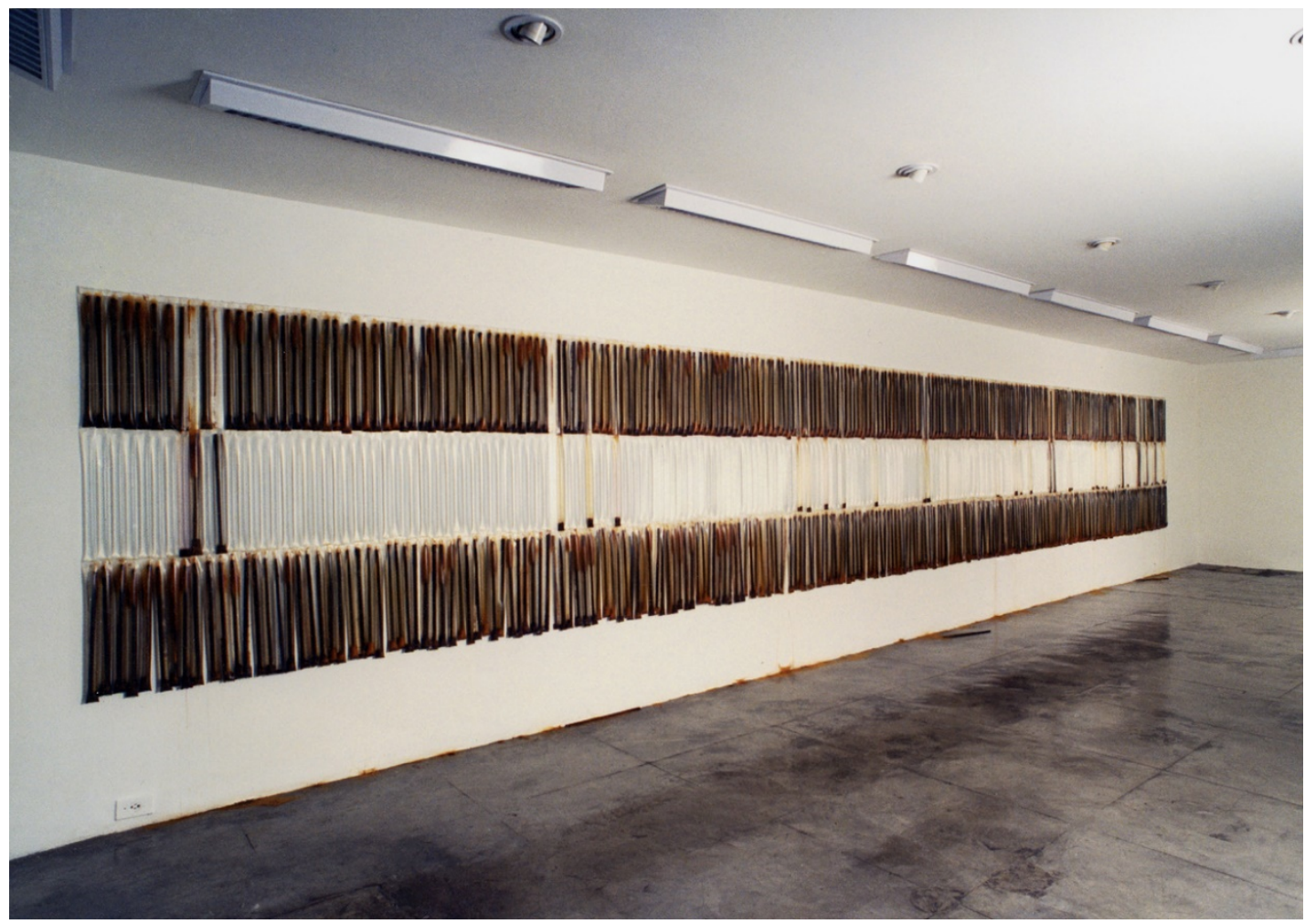

Carla Guagliardi Fifi, 1991

Instalação Galeria Sergio Porto

Foto Vicente de Mello

\title{
Uma Paisagem no tempo ${ }^{1}$
}

Eduardo Coimbra ${ }^{2}$

Estamos ali, diante da história. Um corpo vivo com pele transparente. Células que processam em seu interior o acúmulo da passagem do tempo. Nos falam aos sentidos de uma qualidade tátil e visual do tempo, para além de uma cronometragem exata, de um registro métrico.

O organismo se expande horizontalmente no espaço e verticalmente no tempo. As faixas horizontais, "campos temporais", trazem em si a soma e a diferença, o momento e o lapso, o

\footnotetext{
${ }^{1}$ Texto para o convite/cartaz da exposição Carla Guagliardi - Instalação, na Galeria do Espaço Cultural Sérgio Porto, Prefeitura da Cidade do Rio de Janeiro, de 11 de junho a 7 de julho de 1991.

${ }^{2}$ Eduardo Coimbra é formado em engenharia pela PUC-Rio, começou sua carreira artística no início dos anos 90. A partir do final da década de 90 seu trabalho se concentrou em proposições espaciais, com pesquisas nas relações entre arte, arquitetura e paisagem.
} 
contínuo e a suspensão. As células estendidas verticalmente atravessam o instante, expressam individualmente sua temporalidade, trazem em si a divisão e o múltiplo, e nessa geometria orgânica a serialidade se faz um todo na unicidade do tempo. Um corpo único, que vive e cria seus sinais. Uma escultura onde a matéria permanece em contínua transformação. Reações entre sólido e líquido, escuro e claro, pesado e leve, presente e ausente, antes e depois. Um trabalho que se realiza unicamente naquele espaço e naquele tempo. Uma pintura onde o suporte (a água) é o elemento ativo que traz para o plano o tempo físico, que atualiza a cada olhar uma experiência real e única, que dilui a matéria e se impregna de sua ausência. Uma paisagem que se aprofunda na extensão do tempo.

Estamos ali, diante da obra. Sentimo-nos no mundo. Num mundo como aquele delimitado pela fina película transparente. Contamos o tempo presente, imersos em seus abismos e sobressaltos. Nesse processo silencioso e irreversível comungamos de uma inevitável cumplicidade: a existência.

Junho 1991

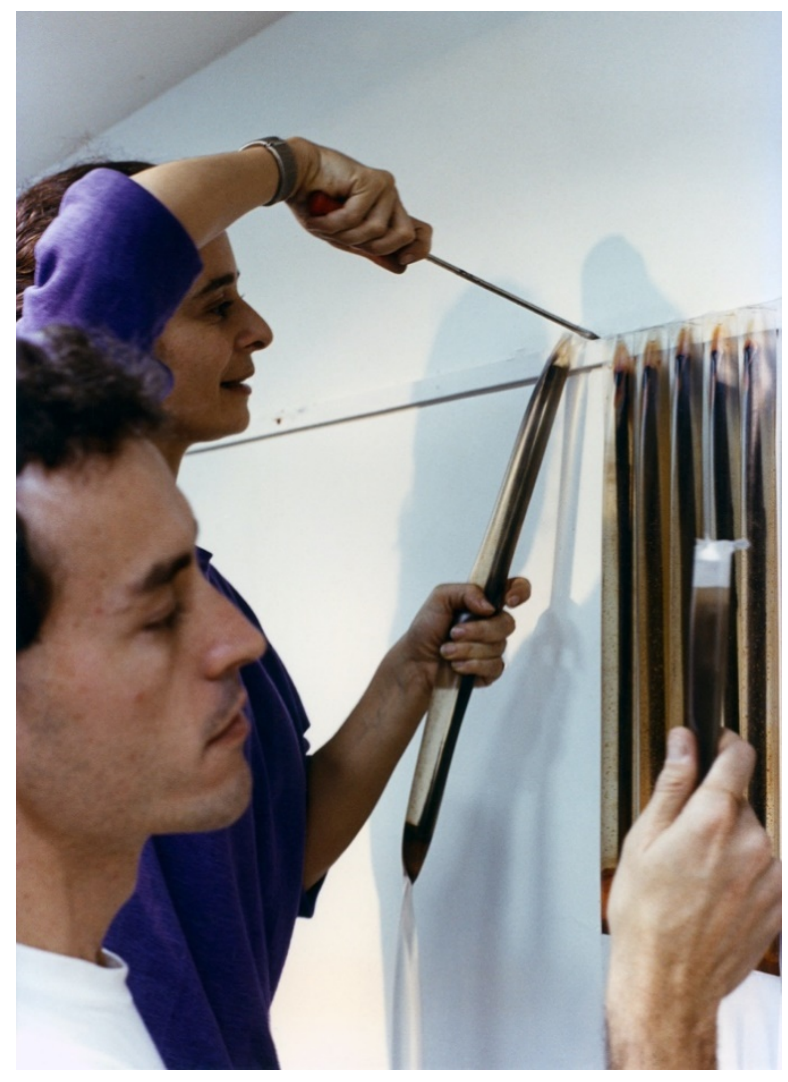

Vicente de Mello

Carla Guagliardi e Eduardo Coimbra na montagem de Fifi, 1991 Exposição Instalação

Galeria Sergio Porto 